\title{
SLOVENŠČINA JANES: POGOVORNA, NESTANDARDNA, SPLETNA ALI SPRETNA?
}

\section{Marko STABEJ, Helena DOBROVOLJC, Simon KREK, Polona GANTAR, Damjan POPIČ, Špela ARHAR HOLDT, Darja FIŠER, Marko ROBNIK ŠIKONJA}

Stabej, M., Dobrovoljc, H., Krek, S., Gantar, P., Popič, D., Arhar Holdt, Š., Fišer, D., Robnik Šikonja, M. (2016): Slovenščina Janes: pogovorna, nestandardna, spletna ali spretna? Slovenščina 2.o, 4 (2): 101-127.

URL: http://www.trojina.org/slovenscina2.o/arhiv/2016/2/Slo2.o_2016_2_o5.pdf.

V sklopu konference Slovenščina na spletu in v novih medijih je 27. novembra 2015 v dvorani Zemljepisnega muzeja GIAM ZRC SAZU potekala okrogla miza z naslovom Slovenščina Janes: pogovorna, nestandardna, spletna ali spretna? K razpravi je bilo povabljenih pet strokovnjakov in strokovnjakinj $\mathrm{s}$ področja slovenskega jezikoslovja: dr. Helena Dobrovolje (Inštitut za slovenski jezik Frana Ramovša ZRC SAZU in Fakulteta za humanistiko UNG), dr. Polona Gantar (Filozofska fakulteta UL), dr. Simon Krek (Inštitut Jožef Stefan, Filozofska fakulteta UL in Fakulteta za družbene vede UL), dr. Damjan Popič (Filozofska fakulteta UL) in dr. Marko Stabej (Filozofska fakulteta UL). Razpravo sem moderirala dr. Špela Arhar Holdt (Zavod za uporabno slovenistiko Trojina in Filozofska fakulteta UL).

Povod za okroglo mizo so bile terminološke zadrege, zaznane pri poskusu poimenovanja jezika v korpusu Janes, ${ }^{1}$ vendar so slednje zelo hitro razkrile širok spekter kompleksnih vzrokov. Vprašanje opredelitve »slovenščine Janes « se tako zastavlja kot rezultat sprememb v načinu človeške komunikacije, po katerih opredelitve in pojmi obstoječe slovenske (in ne le slovenske) zvrstnostne teorije izgubljajo uporabno vrednost. Je mogoče po pojavu spleta in razvoju različnih zvrsti računalniško posredovane komunikacije še govoriti o

\footnotetext{
${ }_{1}^{1}$ Gre za korpus računalniško posredovane komunikacije, ki zajema besedila tvitov, blogov, uporabniških komentarjev in forumov. Korpus predstavlja prispevek (Erjavec in dr. 2015), projektna stran pa je: http://nl.ijs.si/janes/.
} 
javnem in zasebnem, formalnem in neformalnem, knjižnem in pogovornem? Še več, so te kategorije v praksi - v šoli in izven nje - sploh kdaj funkcionirale? Debata se je dotaknila vprašanja, kako naj se jezikoslovje na spremembe $\mathrm{v}$ jezikovni rabi odzove: moramo zagotoviti predvsem novo zvrstnostno teorijo ali je potrebna tudi sprememba v odnosu do jezikovnih uporabnikov, slovenistične metodologije, izdelkov in storitev, ki jih jezikovna skupnost od nas pričakuje, jezika samega? In kakšna je v sliki sodobnih jezikoslovnih raziskav in projektov vloga gradiva Janes, kje so glavne možnosti in kaj omejitve?

Na začetku debate je imel vsak od panelistov nekaj minut za predstavitev izhodiščnega mnenja, sledile so replike in na koncu še vprašanja oz. mnenja udeležencev. Zapis izjav je bil pripravljen po zvočnem posnetku, pri čemer so bile izjave za namene lažjega branja skladenjsko prilagojene značilnostim pisnega jezika, nato pa so avtorji posredovali še nekaj dodatnih pojasnil glede svojih prispevkov. Zapis začenjamo s predstavitvijo prvega panelista.

Damjan Popič: Najlepša hvala. Začel bi malo širše: mislim, da so vse poimenovalne zadrege, ki jih imamo, posledica tranzicije - še ene od tranzicij v slovenskem okolju, ki nam ni najbolje uspela - in to je tranzicija v digitalno okolje. Nekako smo samo z eno nogo stopili naprej. Pri tem največ izkušenj črpam z najbolj prestižnega položaja, ki ga trenutno okupiram, to je položaj tehničnega urednika [revije Slovenščina 2.o], pri katerem imam čast videti, kako se besedilna produkcija udejanja v praksi. Pogosto, pogosto imamo težave ravno pri tem, da smo le na pol stopili v digitalno sfero. Najpogosteje digitalne tehnologije uporabljamo le kot duplikat oz. pripomoček, kako replicirati to, kar je v resnici analogno tvorjeno $\mathrm{v}$ slovenskem jeziku. Podobno poskušamo vse tipologije, ki jih imamo vzpostavljene za knjižnojezikovno tradicijo, prenesti tudi $\mathrm{v}$ digitalno okolje. S temi zagatami se seveda srečujemo vsak dan in vedno bolj, saj se jezikovna raba vedno bolj seli na splet. Kako poimenovati to, kar prikazuje korpus Janes? Verjetno je poimenovanje »nestandardne slovenščine « zaradi dveh razlogov res neustrezno. Prvi je ta, da ni nujno, da gre za nestandardno slovenščino, v določenem segmentu gre za vrednotenjsko 
sodbo. In seveda, če želimo binarizem standardne in nestandardne slovenščine pustiti neobremenjen za nadaljnje opise, je najbrž zelo dobro, da se tega poimenovanja ogibamo. Kar se tiče standardne in nestandardne slovenščine, lahko rečemo, da je v resnici jezik v korpusu Janes povsem heterogen in zato zelo težko poimenujemo to zvrst jezika. Spoštovana kolegica prof. Erika Kržišnik je na Obdobjih² zastavila zelo smiselno vprašanje, ki je večplastno, in sicer: če sem prepričan, da so tviti gospoda Janeza Janše neformalni. Verjetno niso - ali pa so ampak verjetno ne bo šlo s tovrstnimi tipologijami, ki jih imamo vzpostavljene $\mathrm{v}$ tipični knjižnojezikovni produkciji. Morali se bomo osredotočiti na to, da celotni slogovni razpon jezika (torej, kar že poznamo in to, kar prihaja z internetom novega), opisati na binarizmu standardno - nestandardno, za vse nadaljnje opise pa se zanesti na številna jezikovnotehnološka orodja, ki jih imamo seveda tudi za slovenščino kar nekaj na voljo.

Polona Gantar: Hvala za besedo. Na začetku je bilo rečeno, da bo Damjan izpostavil poimenovalne dihotomije, moja naloga pa naj bi bila prenesti to situacijo na slovarsko sceno: skušati ugotoviti, kaj pravzaprav besedišče, ki ga korpus Janes prinaša, je - kakšna in katera je ta leksika. Težko bi govorila zelo na splošno, zato bi mogoče povedala konkretno izkušnjo, ki jo imamo pri izdelavi - bom rekla »slovarja Janes«, čeprav je bilo v izhodišču rečeno, da je to slovar spletne slovenščine. Pri tej izdelavi moramo pravzaprav ugotoviti točno to: kaj bi lahko prišlo v slovar Janes in kaj to je, se pravi - kategorizirati in poimenovati. Zadeve smo se lotili na dva načina. Kot prvo, luščili smo besede iz korpusa tako, da smo štartali iz tega, kaj je v Janesu specifično. Drugi pristop pa je bil, da smo skušali ugotoviti kolokacije, ker smo predvidevali, da bo to tudi pokazalo določene pomenske spremembe. Ko smo se te zadeve lotili, se je najprej postavilo vprašanje ustreznosti primerjave med specializiranim korpusom, kakršen je Janes, in na drugi strani korpusom, ki je splošna slovenščina, tudi

${ }^{2}$ Gre za slovenistični simpozij Obdobja na temo Slovnica in slovar - aktualni jezikovni opis, ki je potekal med 19. in 21. novembrom 2015 v Ljubljani: http://centerslo.si/simpozijobdobja/arhiv-simpozijev-obdobja/2015-2/. 
nespletna slovenščina. Prva ugotovitev je seveda bila, da ne moremo govoriti o »slovarju spletne slovenščine«, ampak da smo na veliko varnejših tleh, če govorimo o »slovarju tviterščine«, »slovarju forumščine «, se pravi besedil oz. žanrov, ki so vključeni v korpus Janes. Hkrati pa se je seveda pokazalo: če delamo ta slovar in smo ugotovili, da je to slovar tviterščine, moramo nekako opravičiti oz. določiti relevantnost teh besed. Zakaj v slovar, katere v slovar? Same po sebi so se ponudile dihotomije, ki jih je že Damjan na začetku omenil: zanimajo nas nestandardne besede, neformalne besede. Zraven tega pa se je pojavilo še vprašanje, kaj je v teh žanrih novega. Ugotovili smo, da smo spet na zelo trhlih tleh. Kar je nestandardno, se je začelo prekrivati s tem, kar dojemamo kot govorjeno oz. govorno; kar dojemamo kot govorjeno, se je začelo prekrivati s tem, kar razumemo kot neformalno. Na drugi strani pa je bilo seveda treba ugotoviti, kaj je novo glede na staro, obstoječe. Tu sta se pokazali dve možnosti. Ena je pravzaprav čisto tehnična: iz korpusa lahko razmeroma preprosto dobimo vse besede, ki jih v drugih korpusih ni. Druga možnost je bila, da pogledamo, kaj je v obstoječih slovarjih že evidentiranega. Recimo, da jezikovna skupnost že uslovarjeno dojema kot tisto, kar ni novo. V resnici se je pokazalo, da je spletna slovenščina oz. slovenščina specifičnih spletnih žanrov pravzaprav presek vsega naštetega. Ne vem, če bom odgovorila na vprašanje, kaj je, ampak nam se je v končni fazi pokazalo, da pridejo kljub vsemu zelo prav opredelitve: »nestandardno «, pri čemer se je jasno pokazalo, da je eno nestandarden zapis, drugo pa nestandarden izbor - to, čemur bi mogoče rekli »neknjižno «. Drugo pa je premik na pomenski ravni: imamo besede, ki imajo nove pomene in ki so nove. To je po moje ta presežek, to, kar nam korpus Janes kar se tiče besedišča lahko ponudi. Še to bi povedala: ker se je gradnja Gigafide nekako ustavila, najdemo v korpusu Janes tudi vse novo, kar je sicer značilno za besedila, ki niso tipično spletna. Prinaša splošni jezik, če temu tako rečem, in kaže premike, ki so koristni tudi npr. za preučevanje splošnega jezika. 
Simon Krek: Jaz bom povedal par stavkov kot nadaljevanje ali mogoče dopolnitev tega, kar sem govoril o pojmu »standardne slovenščine« in »knjižne slovenščine« na simpoziju Obdobja. Glavno sporočilo teh petih minut želim, da bi bilo, naj se ne bojimo izraza »nestandardna slovenščina«. Zakaj? Zato, ker ga rabimo oz. ga per negationem že sproduciramo, če rečemo, da nekaj je »standardna slovenščina « - vse tisto, kar je standardna, je standardna, kar ni, je pač nestandardna. Kako je mogoče preživeti s pojmom »standardna slovenščina « v kombinaciji s »knjižno slovenščino«? V tem članku je moja bazična teza, da je standardna slovenščina nekaj, kar se da opredeliti in je na nek način tudi merljivo, celo strojno merljivo. Za projekt, kot je Janes, je to takorekoč nujno, sicer ne veš, o čem govoriš. Ključni problem pri pojmih standardne in knjižne slovenščine pa je nekaj, kar se v priročnikih in raznih objavah v zadnjem času pojavlja kot »kultiviranost«. In formula, ki sem jo na Obdobjih ponudil za standardni jezik, je: knjižni jezik minus kultiviranost, minus supremacija SAZU. Se pravi, da nima ena inštitucija neke prestižne vloge $\mathrm{v}$ družbi, ampak mora biti tisto, kar se zmenimo, da je standard, konsenz vseh. Najboljši standardi na svetu so konsenzualni. V tem smislu na tej sliki kažem v glavnem črte, važne so v resnici črte. Ko računalniško procesiramo besedila ali govor, moramo povleči neke črte, moramo vedeti, kaj je en jezik, kaj drug jezik. Vedeti moramo, kaj je zapisano in govorjeno. To ni tako težko. Težji del je, da določimo, kaj je standardni jezik - ki ima neke značilnosti. Znotraj standarda so potem žanri, kot recimo uradovalna slovenščina, akademska slovenščina in tako naprej, oba omenjena naj bi bila v celoti standardna. So pa seveda tudi žanri, ki izpadejo iz tega pojma. Če to sedaj opredelimo v razmerju do spletne slovenščine, je to samo medij, kjer se lahko pojavljajo vsi ti žanri. Bazično mislim, da potrebujemo novo teorijo zvrstnosti, ki bo empirično osnovana.

Helena Dobrovoljc: Hvala lepa. Jaz sem želela predstaviti svoj pogled na to problematiko glede na področje, s katerim se ukvarjam, to je pravopis in normativistika. To je pravzaprav povsem drug zorni kot in drug pol. Glede opazovanja nestandardnega jezika in tudi korpusa bi omenila, da prihajamo $\mathrm{v}$ 
obdobje, ki smo ga pravzaprav v tem prostoru oz. v razvoju vseh jezikov že večkrat opazovali. Prihaja do velike stopnje individualizacije pri pisanju na internet kogarkoli od nas. Govorimo o tem, da ljudje sledijo ideologiji pristnosti, hkrati pa uporabljajo v sicer nezaznamovanem govoru in pisanju prvine, zaradi katerih so opazni. Težko bi trdili, da je v teh zapisih, blogih, tvitih uporabljen nestandardni jezik, sploh ne, pogosto so uporabljene pogovorne prvine zaradi poudarjanja in prav zaradi želje po vzbujanju pozornosti. V preteklosti smo bili priča podobnim razmislekom ob nastanku teorije žanrov, o čemer nam priča Bahtinovo kultno besedilo o diskurzu v romanu; 3 že v 7o. letih ugotavlja in obžaluje, da se stilistika ne ukvarja z vsakodnevnim diskurzom, temveč z nekimi historičnimi vzorci. Nekako takole zapiše: stilistika ignorira diskurz na trdih ulicah, cestah in vaseh, diskurz družbenih skupin. Opozarja tudi, da je stilistika odrezana od družbenih modelov, v katerih jezik pravzaprav živi. Te besede nas spominjajo na situacijo, v kateri se nahajamo danes. Bahtin govori o centripetalnih in centrifugalnih silah, torej tistih, ki ustvarjajo naš skupni, enotni jezik, kakorkoli ga že poimenujemo, in pa tistih, ki ustvarjajo raznoliko jezikovno realnost, to pa je ta heteroglosija. Za normativistiko je raziskava centrifugalnih sil pravzaprav napoved potencialnih jezikovnih sprememb v knjižnojezikovnem standardu. Za nas je morda manj pomembno, kako ljudje ta trenutek nekaj zapišejo na splet: ali je to povsem pogovorno ali napisano z diftongi v želji pisca, da pokaže svoj regionalni izvor. Za nas je bolj zanimivo tisto, kar se kategorialno izkazuje kot premik. Npr. tisto, kar sta predstavili včeraj Kaja in Špela: ko gre za sistemske spremembe v skladenjski strukturi ali npr. spremembe na ravni oblikoslovja. Vprašanje pa je, katere od zaznanih sprememb so mogoče spremembe v knjižnojezikovnem standardu. V zapisih je npr. opazna denimo maskulinizacija nevter: dejansko se izgublja srednji spol, npr. pri primerih tipa sonce je bil do enih $v$ nedeljo. Tega je res veliko. Ne vem, če ste to opazili tudi drugo spremembo v zapisih, npr. razne spremembe v ženski spol, npr. da uporabiš SPD pedale, pa natakneš si očale.

3 Besedilo The Dialogic Imagination: Four Essays, ki je izšlo leta 1981. 
Neverjetno, da se to tako pogosto pojavlja v zapisanem jeziku. Potem imamo tip zloženk, ki so besedne zveze, tj. hospic oskrba, pa tudi nekatere tipe zapisa, ki jih že tradicionalno spremljamo kot neustaljene, pri zapiranju zeva npr. amoniak, celuloid, higiena, pacient, danes že amonijak, celulojd, a le na spletu higijena, pacijent. Podobno je s soglasniškimi sklopi st, sp, ki jih vse pogosteje zapisujemo fonetično, tudi $\mathrm{v}$ formalnih in javnih nespletnih besedilih, in to kljub nasprotnim napotilom v priročnikih knjižnega oz. standardnega jezika, npr. stadion nasproti štadion, start nasproti štart, štopali smo in podobno. Tako rabo lahko opazite, če gledate recimo Siolov novičarski portal. No, to so spremembe, ki nas zanimajo, ker ne gre samo za posamezne, torej sporadične primere, ampak za premike, ki jih bomo morali evidentirati. Poudariti je treba še to, da ta spletni jezik živi kljub odsotnosti institucionalnega usmerjanja in živi zelo uspešno. Kar pomeni, da se lahko sporazumevamo brez šumov, čemur je tudi treba nameniti razmislek. Kar pa se tiče razprav o standardnem in knjižnem in kultiviranosti (to se nanaša direktno na Simona): eno so plakativne izjave jezikoslovcev - enega jezikoslovca, dveh, treh - drugo pa so konkretni rezultati dela, kjer se razmišljanja dejansko pokažejo v praksi.

Marko Stabej: Hvala za povabilo, veseli me, da sem tukaj. Imam predlog, kako poimenovati slovenščino Janes: to je »poljubna slovenščina «. Oziroma "poljubna pisna slovenščina «. Tudi iz tega, kar so pred mano povedali in povedale, se kaže, da je dejansko ne moremo miselno stereotipizirati. Je pa za normalno delovanje jezikovne skupnosti in vse pedagoške dejavnosti stereotipizacija seveda nekaj zelo nujnega. Kot je rekel že Damjan, smo v tranziciji, in kako bo ta tranzicija potekala, je precej odvisno tudi od krogov, ki to raziskujejo. Mislim, da je vsaj z jezikoslovnega stališča ključno vprašanje, čemu sploh počnemo to, kar počnemo. Tukaj je ogromna razlika, de facto ogromna razlika v znanstveni skupnosti, zlasti v jezikoslovni skupnosti, ki se je mogoče premalo zavedamo. Zlasti pa se je ne zaveda javnost, zato tudi vse te peripetije: »Zakaj se vseeno ne morete zmeniti«. Tako, mimogrede. Zdi se mi, da ta binarizem pravzaprav ni standardno - nestandardno, vsaj kakor ga jaz 
skušam izluščiti iz tega, kako se je raziskovalo slovenščino in kako se jo še sedaj raziskuje. Binarizem je visoki knjižni jezik, super duper, tisti nekaj res, in pa narečje, pristno, neomadeževano z drugimi narečji, s čimerkoli. Vse vmes je ne knjižno, ne narečno, ne standardno, nič. To je zelo udobna pozicija, zato ker imaš dve sorazmerno oz. na videz jasni ... Ne vem, kaj naj sploh rečem. Niti ne jezikovni praksi, ampak prečiščeni model neke domnevne jezikovne prakse, za katero nikoli ne veš, ali je kdaj bila, ali naj bo, ali sploh kdaj bo ... In potem to na nek način teoretično utemeljuješ $\mathrm{z}$ naslagami najrazličnejših takih in drugačnih psevdofilozofij, psevdoteorij in tako naprej. Kdorkoli od nas (tukaj so sami taki, ki so to že kdaj počeli) je kdaj poskusil raziskovati, kaj je vmes, je imel v resnici strašne težave. Ne, če je imel podatke in je govoril: tega je toliko, tega je toliko in tega je toliko, ampak ko pride do onih odstavkov, ko stereotipiziraš. Tam si pa bos. Tukaj ni kolegice Maje Bitenc, ki imam priložnost, da sem ji mentor. Ona, kot najbrž marsikdo med vami ve, gleda, kaj se $\mathrm{z}$ govorci dogaja, ko dnevno migrirajo iz enega okolja $\mathrm{v}$ drugega. ${ }^{4}$ In ugotavlja, da se dogaja cel svet. Najrazličnejše. Da sploh ni odvisno od tega, v katero govorno situacijo pade človek, ker ljudje lahko po svojih navadah popolnoma drugače reagirajo, pa so iz istega okolja. Zato se mi zdi, da z raziskovanjem "produkcije vmes « greš v zelo močno cono neudobja - ki ti poraja dvome, ki jih hočeš izraziti in si s tem pravzaprav na nek način sovražen skupnosti, ki uživa v raziskovanju udobnega. In zato nas in vas marsikdaj ne razumejo. Je pa treba vztrajati, se mi zdi. Ne vem, zakaj raziskovati: ker nam je to fajn, ker je malo seveda tudi neke vrste uporništvo ... Najbrž zato, ker skušaš ugotoviti, kakšna je jezikovna praksa. Ali pa greš v najrazličnejše smeri, kamor niti sanjamo še ne, da bi šli. Kaj je s psiholingvistiko, kaj je s (ta pravim) kognitivnim jezikoslovjem? To so nedotaknjena področja. Strinjam se pravzaprav z vsem, kar so rekli, treba je preurediti teorijo žanrov. Ampak to, kar je Helena povedala s stališča posameznika, je treba tudi preurediti - ali pa sploh postaviti teorijo jezikovne zmožnosti: zakaj kdaj nekaj počnem, zakaj v

4 Predstavitev razsikave je na voljo v (Bitenc 2013). 
isti jezikovni situaciji ne počnem istega kot nekdo drug? Je kaj narobe z njim ali $\mathrm{z}$ mano ali je z nami vse v redu? V tem smislu nas čaka ogromno dela, da bomo zmogli to novo realnost, ki v bistvu ni tako nova. To je bilo moje izhodišče: večjezičnost, tudi pisna, je bila že prej, že od nekdaj, ampak je bila spravljena varno v zasebno korespondenco in tako naprej, ni bila tako javna in vidna. Če hočemo to raziskovati, je pomembno, kar je Polona izpostavila (na kratko in jasno): ne moreš sploh začeti stereotipizirati. Važno je, da si avtentičen, da je vse dokumentirano, o stereotipizaciji, ki je nujna, pa se moramo dogovarjati. Zato so taki paneli, ne samo paneli, nenehno sodelovanje je nujno. Ker brez pametne stereotipizacije ne bomo prišli nikoli v šolo. In če ne prideš v šolo, ne prideš nikamor. Tukaj se mi zdi, da je največja težava vsega skupaj. To je to.

Špela Arhar Holdt: Najlepša hvala vsem skupaj. Vidim, da ste si vmes marsikaj zapisali, zato bi morda začeli kar z neposrednimi replikami na te izhodišče izjave? Če ima kdo kaj? Precej ste se strinjali, kar je problematično za panel (smeh). Mogoče lansiram kakšno provokativno misel, pa se lahko strinjamo okrog tega, npr. »kaj pa je s to računalniško slovenščino ...«? Ne, hecam se. Eno vprašanje, ki ste ga sicer vsi odprli, nihče pa ga ni skušal reševati, je vprašanje: kaj bo torej z novo žanrsko teorijo? Kako pristopiti k formiranju te teorije? Sedaj imamo sicer novo korpusno gradivo, ki pa je bilo že zgrajeno na tak način, da so bili žanri vnaprej izbrani. Kako začeti in kdo je pravzaprav odgovoren - ne kot posameznik, ampak katera inštitucija naj bi se s tem ukvarjala in kdaj lahko pričakujemo ta rezultat? To je bila sedaj provokacija.

Simon Krek: Lahko jaz (smeh), saj bom kratek. Malo polemike vseeno. Eno vprašanje raziskovanja je: zakaj nekaj počnem. Kjer pa se jaz sam počutim veliko bolj udobno, pa je, da gledam rezultate teh dejanj. To pomeni, da smo zabeležili nek govor, zabeležili smo, da je nekdo nekaj zapisal. Seveda se moramo vprašati tudi, zakaj je to naredil, ampak dejstvo, da nekaj je naredil, je zame že dovolj, da lahko s tem nekaj naredim. Kaj lahko naredim? Primerjam z drugimi dejanji te vrste in če odkrijem, da so med dejanji podobnosti, potem lahko rečem, da je mogoče to nekaj, kar lahko opredelim z neko kategorijo. To 
se mi zdi zelo pomembno, zato poudarjam empirično osnovo nove teorije žanrov, ki bi si jo človek želel. V resnici je fino raziskovati tudi, zakaj nekdo nekaj počne, ampak v tem smislu - praktičnem in zadosti stabilnem, da to lahko pride tudi v proces edukacije - se mi pa zdi, da je pač treba zastaviti na ta način. Par stavkov bom še povedal. Razmišljal sem tudi o svojem lastnem procesu edukacije, kaj sem izvedel o žanrih. Ne vem, koliko se boste spomnili svojih osnovnih in srednjih šol in tako naprej, ampak jaz sem začel hoditi v osnovno šolo leta '73. Hu, a ne (smeh)? In sem čez nekaj let (že zelo mlad) naletel na nekaj, kar se je imenovalo »interesna govorica«, kjer je bilo navedeno, da obstaja nekaj kot žargon, nekaj kot sleng in nekaj kot argo. Prva dva sem nekako razumel, argo pa je bil ... Teoretski psihoanalitiki bi rekli »objekt mali a«: veš da je, po celi edukaciji je, ampak ne moreš ga prijeti in dela samo zgago. Tam so sicer navedeni primeri kot kapatopotaka, ja, dodajaš neke zloge. Potem sem pa v knjigi Andreja Skubica 5 odkril primer - ker se je tudi on zelo trudil z argojem, kaj s tem narediti, ker je pač delal cel doktorat iz žanrov, sociolektov - in je odkril, da se kriminalci pogovarjajo po zaporih s skrito govorico. Ko on reče: »A imaš prašek? «, recimo ... (smeh). Takrat sem poštekal, kaj naj bi ta argo bil v resničnem življenju. Ker ta koncept se potem nenadoma razširi na celotno pragmatiko govorice. Kot če rečeš: »A bi šla v kino? «, s tem da upaš, da boš lahko igral videoigrice - in se ta skriti pomen izjave imenuje argo. Se pravi, v celi govorici obstaja skriti pomen, ki je zadaj za tem, kar je na prvi ravni jasno. Razumete, kaj hočem reči: imaš jezikovni objekt, koncept, ki ga ne moreš prijeti. V novi teoriji žanrov bi moralo biti vse jasno dokazljivo - na način, kot ni bilo mogoče pokazati do Skubica, da argo v jeziku zares obstaja.

Marko Stabej: Ne strinjam se s tabo, da bo bolje ... (smeh) Ta »zakaj« je problematičen. Z znanstvenega stališča je »zakaj« seveda najbolj zoprna zadeva (in pa mikavna) in se je je najlažje odreči v smislu empiričnosti. Jaz nisem toliko govoril o tem, da bi pojasnjevali vse »zakaj«. Ampak to, kar je Helena nakazovala: do stališča posameznikovega integralnega jezikovnega početja se

5 Knjiga Obrazi jezika iz leta 2005. 
seveda nujno moraš vprašati (temu lahko rečemo tudi pragmatika), zakaj nekje nekaj zakriva, kakšni so kontekstualni znaki ... Če se tega ne sprašuješ, lahko slabo interpretiraš korpus. Oz. kar je deloma tudi naša krivda ali krivda korpusarjev, da rajši delaš tiste korpuse, ki jih lažje narediš. Najlažje narediš tiste korpuse, za katere najlažje dobiš financiranje. Tudi prijava Janes je uporabljala argumentacije, ki so bile všeč stereotipnim predstavam financerja, ne pa najbrž dejansko željam te skupnosti: da bomo ugotovili, koliko je neslovenskega $\mathrm{v}$ Janesu in podobno. To so neki taki kompromisi. Ampak hotel sem reči, da se sprašujemo, zakaj ljudje - aha, spet »zakaj«, pa si me dobil (smeh). Ali pa: kako to, da počnejo, kar počnejo, ali počnejo vsi enako itd. Vse pa je empirično, tudi vprašanje razumevanja se da empirično, ampak je seveda neskončno težko, ker preden karkoli dokažeš ... Moraš zasnovati eksperiment, s katerim lahko gre zmeraj kaj narobe, zmeraj ostaneš na področju tistega »nismo pa še tega in tega«. Kar pa konec koncev ni nič takega. Včasih spremljam dogajanje na področju psihologije in se mi nenehno zdi, da se psihologi, ki so metodološko tako zelo natančni, celega kupa zanimivih stvari nikoli ne lotijo, ker je jasno, da ne bodo mogli speljati tako, da jim ne bi mogel kdo očitati metodologije. Po drugi strani je jezikoslovje ravno zaradi neempiričnosti polno nekih naivnih, prehitrih posplošitev, ki pa zelo hitro gredo kar v šolo, spet v edukacijo. Pri teoriji zvrstnosti je zelo mogoče dokazati, da je bila neuspešna ravno v svojih svetlih namenih: pokazati, da je jezik kontinuum, ki ima različne pojavne oblike. Ampak ni uspelo. Pri tem premisleku zame ostaja veliko vprašanje: ta teorija ni bila ne vem kako komplicirana, res pa je bila rahlo zlagana. Kakšno narediti, da se jo bo dalo uporabiti? O vsej tej žanrski razpršenosti je pravzaprav zelo težko govoriti že z ljudmi, ki so izobraženi, kaj šele s kom, ki ... Ni model, ki bi bil intuitiven. Ta prav - narobe je nekaj strašno intuitivnega (smeh).

Helena Dobrovoljc: Tukaj se strinjam. Zdi se mi, da se $v$ našem jezikoslovju zaplete, ko gremo v detajle in želimo žanre preveč, preveč podrobno in monolitno opredeljevati. Mislim, da je za trenutne potrebe bolje - tako, kot 
je Simon govoril o besednih vrstah -, da naredimo korak nazaj in poskušamo najprej pogledati z distance, glede česa se strinjamo. Res je, da sintezo lahko naredimo šele po empirični raziskavi, ki je seveda podrobna. $\mathrm{S}$ tega vidika bi rekla, da je poljubna slovenščina, kot je rekel Marko, pravzaprav znanilka jezikovnih sprememb. Jezikovne spremembe tega tipa so opazne najprej pri mlajših generacijah, ko te odrastejo, njihov jezik postane tudi jezik starejše generacije, in to potem postane del različnih žanrov, ki jih je zelo težko sekati. Izbiramo enkrat to, drugič drugo - glede na okoliščine, ki niso samo žanrske. Tu bomo zelo težko delali ostre meje.

Marko Stabej: Hvala, ker si uporabila termin (smeh).

Helena Dobrovoljc: Ali pa »skupni jezik«.

Špela Arhar Holdt: Poljubna pisna slovenščina je res simpatično poimenovanje, ne vem pa, če je v opoziciji do realne, materialne, nespletne, nejanes slovenščine? Občutek imam, da je slovenščina Janes oz. to, kar ta korpus predstavlja - računalniško posredovana komunikacija - samo preslikava (seveda z določenimi spremembami) komunikacije, ki smo jo itak že prej imeli. Pri čemer se seveda razmerja avtorstva, lektorstva in vse te inštitucije, ki smo jih navajeni, v določenih točkah spreminjajo, so na drugačen način razvidne. Ne vem, če je bolj poljubna od ...

Marko Stabej: Ne, ne, saj ni, samo razkriva to bolj. Mislim, če smem ... No, najprej izrazim obžalovanje, da včeraj nisem bil na Janesu zaradi jezikovnopolitičnih agitacij. Ampak kot recenzenta me je najbolj prepričalo, da je nujno tako stvar imeti, ravno tisto, kar je bilo v nekaj prispevkih: da ta "poljubna« slovenščina kaže večjo regularnost kot ... (smeh) »Urejevalna slovenščina «. Zdi se mi zelo fajn, da lahko dokažeš te stvari, ki jih slutiš, ampak ti pride kot ... Ne vem, kaj naj rečem, kot kosilo lačnemu. Kakšne so pa implikacije, pa ne vem. To je pa res tisto, kar nam kvaziliberalnim ves čas očitajo, da »Ena pravila pa morajo biti«. Mu rečeš: »Ne, ravno obratno, pravil ne sme biti, pa bo komunikacija šla $\mathrm{k}$ enotnosti«? To potem postane 
družboslovno vprašanje. Že ob slovarski monografiji ${ }^{6}$ se mi je zdelo, da nam določeni družboslovni vidiki manjkajo v smislu: kaj je, kakšen organizem sploh je jezik? Kakšna skupnost je tista, ki je vendarle enotna v različnosti? Vsi na nek način slutimo, da se res ni treba tako préklati okrog čisto vsake dvojnice - ravno zaradi neke samozavesti, da si skupnost želi ta jezik imeti. Dokler pa je mogoče igrati na karto strahu, da: »Ja, ja, ampak če ne bomo pazili, pa te skupnosti več ne bo« ... Pazili na kaj, tega pa nikoli ne veš. Zdaj bom šel čisto na drugo jezikovnopolitično, ampak ravno to vprašanje jezikovne izbire: zadnjič sem gledal Aritmični koncert, kjer je bil Hamo (Šalehar, bluesman) in je vmes direktno povedal, da je samo v amerikanščini ta pravo, cel žur in to. In ga niso vrteli, ker na RTV nočejo vrteti angleških. Je rekel, potem pa sem se zbrcal, čisto oportunistično, zdaj pa sploh ne morem več teksta v angleščini napisati, mi je pa fajn. In - kaj zdaj? Očitno neka prisila mora biti, ali kaj? Ali pa ne, ne vem, mogoče bi bilo bolje, če ga ne bi nihče poslušal in bi še naprej v angleščini ... (smeh) Ampak to so družboslovne stvari, ki se jih jezikoslovci ljubiteljsko dotikamo, o njih debatiramo, ampak v resnici ne vemo. Družboslovci pa se s temi stvarmi praviloma ne ukvarjajo. Ali pa skoraj nikoli ne, ne vem, ali pa ne povejo. Ali pa mi ne vemo.

Polona Gantar: Jaz bi mogoče dodala samo to: fajn se mi zdi, Helena, ko si rekla, da na eni strani v tej skupnosti ves čas obstaja potreba ugotoviti, kaj je prav in kaj narobe - ljudje pišejo, ob vsaki dvojnici se to vprašajo in svetovalnica ima ogromno dela. Kljub temu pa hkrati povsem normalno živi ta druga slovenščina (ki seveda ni črno-belo druga, soobstaja), kjer so govorci popolnoma zadovoljni s tem, da jih nihče ne korigira in da se popolnoma normalno obnašajo. Hočem reči: njihova izbira nestandardnosti je zavestna, je namerna.

Helena Dobrovoljc: Tukaj se res lahko navežem na čisto praktično izkušnjo. Ko smo začeli s svetovalnico, so prihajala zelo stereotipna vprašanja.

${ }^{6}$ Gorjanc in dr. (ur.) 2015. 
To, kar smo rekli: kaj je prav med dvema in tako naprej. Po dveh letih in pol delovanja (zdaj imamo 1200 odgovorjenih objavljenih vprašanj) pa moram reči, da se je tudi način spraševanja spremenil. Ljudi ne zanima le odločitev med dvema izbirama, ki jih imajo: vprašajo tudi »zakaj je tako«. Ko mu eno in drugo pojasniš, velikokrat dobimo odziv, da je s tem zadovoljen, da ga zanima tretja možnost ... To je sedaj že postal dialog. S tega vidika se mi zdi, da se tudi jezikovna skupnost osvešča, spreminja in sprošča. To se da tukaj tudi praktično pokazati in videti.

Simon Krek: Še eno stvar bi dodal na to, ker se mi zdi relativno ključna. Izhaja pa ravno iz tega, kar je govoril Marko: družboslovnega dela. Pri tej izbiri, o kateri tukaj ves čas govorimo, je v resnici ključna intenca avtorja: ali je moj primarni namen, ko nekaj ubesedim, komunikacija brez dodatkov (kot recimo po družbenih medijih in tako naprej) ali je intenca doseči nek učinek - in sicer učinek, da mi nihče ne bo rekel, da nisem znotraj standarda. To je zavestna intenca tistega, ki sprašuje na svetovalnico: kakšen učinek bom dosegel, če bom naredil to ali če bom naredil to. $V$ resnici ves čas sprašuje po nekem takem bizarnem feedbacku. In zakaj? Zato ker imamo v tej družbi tako situacijo, da je to pomembno. Če to ne bi bilo pomembno, od cele edukacije naprej, potem tega pač ne bi spraševali. S tem vprašanjem se je treba spopasti. Dokler bodo ljudje spraševali v smislu intence - kakšen bo diskurzivno učinek tega, kar počnem do takrat bo moral obstajati pojem standardnega jezika. Ne moremo se temu izogniti.

Damjan Popič: Jaz bi mogoče dodal samo to: v okviru konference Janes smo imeli izjemen statistični tutorial7 in na eni podmnožici podatkov smo lahko videli, da na Twitterju velik del uporabnikov izkoristi 140 znakov - kolikor jih imajo na voljo, do konca. V tej situaciji je izbira, ki jo je Simon ravnokar omenil, bistveno drugačna kot pa v e-pošti ali katerem koli drugem spletnem okolju, ki

7 Delavnico z naslovom Beyond example extraction: Quantitative analysis of the JANES corpus je vodila Maja Miličević. Gradiva so dostopna na: http://nl.ijs.si/janes/dogodki/konferenca-2015/\#Predkonferencni_tutorial. 
ni omejeno. Zato se mi zdi, da je zelo težko najti krovni termin za vso to slovenščino, če ni seveda takšen, da je poljubna, ki nekako združuje vse te izbire v vseh možnih okoljih.

Špela Arhar Holdt: Mislim, da je projekt Janes v tem smislu presegel tudi pričakovanja samih prijaviteljev, ker se poleg tega, kar je nestandardno, pojavlja v tem korpusu zelo veliko standardnega - ker je preslikava normalne komunikacije v drugem mediju. Tudi to je bil eden od izzivov, se mi zdi, oz. še vedno je: kako sopostavljati to dvoje v novem mediju, če še ni bilo ustrezno sopostavljeno prej, pred računalniško posredovano komunikacijo. Podvprašanje ali misel, preden odpremo debato še za publiko: je ta temeljna dvojnost, ki bi jo bilo treba v procesu izobraževanja najbolj izpostaviti, razlika med javnim in zasebnim $\mathrm{v}$ komunikaciji? Ta se mi zdi v slovenskem prostoru najbolj določujoča za izbiro jezikovnih elementov. Ali formalno - neformalno?

Marko Stabej: Pri vsakem takem omejevanju moramo biti zelo previdni. Dve stvari bi na kratko povedal. Ena čisto nepovezana izhaja iz izkušenj našega Centra pri poučevanju otrok priseljencev in njihovih staršev. Ideja je, da starše, ki nimajo pojma o slovenščini in se morajo integrirati v slovenski šolski sistem - da pretežno mame (oz. če smo čisto iskreni, samo mame) naučiš, kaj je šolski sestanek, šolska torba, kaj so copati ... In so bili zelo hvaležni in to je bilo ganljivo. Ampak izjava neke gospe je bila: »Rada bi se naučila pravo slovenščino, da bi lahko bila še kaj drugega kot mama (čeprav sem zelo rada mama)«. Drugo pa je anekdota o zasebno - javno, ki jo nekateri že poznate. Pred nekaj leti mi je telefonirala stara gospa, mislim, teta (tako se je slišalo). Pravi: »A ste vi tisti Stabej z radia? A vas lahko nekaj vprašam? « Sem rekel: »Seveda.« »Tukaj sem, na morju v Ankaranu, pa bi rada vnukoma pisala razglednico, pa me zanima, če sem prav napisala. A mi lahko to poveste.« Sem rekel: »Kaj ste napisali? « in sva se zmenila ... Ampak me je šokiralo, zakaj ... In mi je tudi povedala, zakaj: »Ker sta učena, pa da ne bosta mislila, da jaz sem pa ta zadnja reva«. To je popolnoma zasebna komunikacija. Ne vem, saj mogoče imaš prav: ozaveščaš, da je zasebno lahko vse sorte, za javno pa opredeliš, kje 
moraš pa »merkat«. Ampak kot smo videli tudi na Obdobjih, hitro lahko postane, da zelo jasno določaš, do kod je meja javnega, in zelo jasno poveš: do tukaj si lahko, kar hočeš biti, od tu naprej pa bodi točno to. Pedagoško je skoraj nujno, da nekako stereotipiziraš, ampak hkrati pa lahko povzročaš nove nesporazume ali pa podaljšuješ stare.

Špela Arhar Holdt: Torej samo v kombinaciji z odrekom »kultiviranosti«, kot je bilo prej postavljeno? Pri tej razglednici je bil najbrž problem, da je ona čutila ... Problem je bil v kultiviranosti.

Marko Stabej: Vem, ampak kaj pa boš kot starš, kot sem nekaterim že težil? Otrok ti reče lih za lih, fajn, lih za lih. Bo napisal lih za lih, kaj mu boš rekel: »Ah, to je pa drugače? « Kaj boš rekel? »To pa ni najbolj fajn? « Potem pa on: "Zakaj? « Kaj, ker je to popačena nemščina? Dosti je en korak, pa prideš nazaj $\mathrm{v}$ točno te stare fore.

Helena Dobrovoljc: Jaz bi se pridružila temu, da je zlasti v šoli treba biti zelo previden. Zdaj imam to izkušnjo, da lahko prebiram berila v prvi triadi devetletke. Kakšna revolucija je bila narejena na tem področju z aktualizacijo besedil! V leposlovju smo bili že prej priča individualizmu in želji po pristnosti: pisatelj je uporabljal nestandardne oblike, izraze, ker je želel približati bralcem pogovorno slovenščino v dialogu. Problem je, ker se to zbliževanje s sodobnimi besedili v srednji šoli neha. Pred kakim letom smo se na Univerzi v Novi Gorici srečali s primorskimi srednješolskimi profesorji in pogovarjali o pouku jezika $\mathrm{v}$ srednji šoli. Problem se pojavlja tudi tam, to pa zato, ker se ob pripravah na jezikovni del mature ukvarjajo samo $\mathrm{z}$ neumetnostnimi besedili. Torej, strokovna besedila, vsi se učijo za maturo, da bodo znali tam prepoznati termine in podobno. Ne obravnavajo pa slovenskega leposlovnega besedila (kjer se pojavlja tudi pogovornost, sleng in vse nestandardno) z vidika jezikoslovja, ampak to samo berejo za čtiva. V osnovni šoli se še odvija pouk slovenskega leposlovja, v srednji premalo. Tudi to je tudi neke vrste ozaveščanje. Kasneje, v letih, ko človek morda že drugače presoja svoje jezikovne izbire, to manjka. 
Špela Arhar Holdt: Ok, sedaj bi res dala besedo, možnost še publiki. Darja? Darja Fišer: Najprej najlepša hvala, počutim se, kot da je moj rojstni dan (smeh), res sem zelo vesela in zdi se mi tudi, da ste briljantno opravili to nalogo. Zdi pa se mi, da smo se oz. ste se o tem, kakšna je slovenščina Janes, ukvarjali predvsem s stališča kakšna je, ne pa toliko čigava je. Zame je to ključna razlika tega korpusa z ostalimi, ker - politično nekorektno - se mi zdi edini skupni imenovalec korpusa, da je to slovenščina »Janesov«, slehernikov, posameznikov. Ti so zelo različni in slovenščino na družbenih omrežjih uporabljajo za različne namene, ampak so navadni ljudje. V Gigafidi, Kresu ${ }^{8}$ pa niso navadni ljudje, so poklicani ljudje, ki pišejo, ker so za to izobraženi, nadarjeni, plačani. To se mi zdi največja razlika: da gre nekurirano vse v eter. $O$ tem me zanima vaše mnenje. Druga stvar, ki jo sama opažam, pa se kot jezikoslovka ne znam ustaviti in zamejiti, je pa to, da ko vidiš zanimivo slovenščino, je zelo spolarizirana. Velika večina je standardne, nezanimive, potem imaš pa dva zanimiva koša: ena je zanimiva zato, ker se ljudje zavestno umikajo od norme in se z jezikom kreativno igrajo. Tega je recimo na Twitterju zelo veliko. Druga mi je pa zanimiva zato, ker ljudje ne delajo nobenega zavestnega odmika, celo trudijo se lepo pisati. Recimo na forumih: prav vidiš, da začne z najboljšimi nameni, potem pa tisti jezik propade in do konca se jim sploh ne znese več kontrolirati. Zdi se mi, da je treba ta dva fenomena gledati na različne načine.

Marko Stabej: Sicer gledam od daleč, ampak a ni to osnovna past korpusnega jezikoslovja? Dinamike znotraj teksta in pa tudi posameznika ne moreš videti, ga žrtvuješ na račun ... To je plemenito žrtvovanje, ampak ne smeš teh stvari - če hočeš resno, celovito analizirati - vzeti ven. Tudi to, kdo tvita, kdo ne tvita ... Je slehernik, ampak spet take vrste slehernik, ki mu je do tega, da ... Ne vem, najbrž bo to vse bolj prevladujoč slehernik, ampak ... Meni se zdijo z analitičnega stališča to zelo relevantne stvari. To vidim nasploh pri

\footnotetext{
${ }^{8}$ Referenčna korpusa za slovenski jezik (Logar in dr. 2012), dostopna na www.gigafida.net in www.korpus-kres.net.
} 
jezikovnem opisu (slutim, se pa tega ne znam niti približno lotiti): nekonsistentnost jezikovne izbire s tradicionalnega stališča. Navajeni smo in tudi edukacija, kot je rekel Simon, nas pelje k temu, da je dobro, da si dosleden, da izpelješ, da ne uporabljaš konkurenčnih sinonimov ... Saj je dovolj, če gremo na področje terminologije, kjer se je že stokrat izkazalo, kako je s terminološkim wishful thinking: predopredeljeni, nevariantni, konsenzualni ... Ko greš pa gledat $v$ tekst, se ti vse podre, ker je ena sama variantnost, en sam boj, ena sama nenantančnost. Ne ena sama, ampak ogromno tega. To je spet tista cona udobja in neudobja, ne morem si kaj. Cona udobja je: »Aha, to je to, tisto iščem. « Cona neudobja pa je, da ne veš, kaj poimenovati, ne kaj vzeti, ne kaj zajeti, ne kaj o tem reči ... Ampak očitno se da, če imamo konference in take stvari.

Špela Arhar Holdt: Ok, ima še kdo odgovor na to, še kaj za dodati?

Polona Gantar: Zdi se mi fajn, da je Darja izpostavila, kaj je najmanjši skupni imenovalec. Ni to, da so to »navadni« ljudje, ker je zelo težko določiti, kaj so »navadni«. Ljudje, ki tvitajo, ljudje, ki pišejo komentarje, ljudje, ki pišejo bloge - to je v bistvu skupni imenovalec. Tako navadni kot nenavadni. Celo bi rekla, da bolj ko si nenavaden, rajši tvitaš (smeh). Drugo pa je, kar je Marko rekel v zvezi z glih za glih oz. lih za lih. Mislim, da tukaj vseeno podcenjujemo naravno izbiro pravega žanra oz. diskurza (kakorkoli že) in da to pride pač z usvajanjem jezika.

Marko Stabej: Ja, ampak pride s povratno informacijo, brez povratne informacije pa ne.

Polona Gantar: Seveda in dlje ko si govorec, več je teh situacij in se potem tudi znaš odločiti - glede na to, da si iz konkretnih situacij ugotovil, da lih za lih ne paše, poskusiš kaj drugega ... Hočem reči, da podcenjujemo, če trdimo, da se ljudje ne znajo obnašati.

Marko Stabej: Nikogar nisem hotel podcenjevati, je pa realna možnost, da se ob tem, ko se naučiš to početi, navlečeš take ali drugačne refleksije. Lahko rečeš v smislu standardnosti: »Dobro, tako je, včasih je veljalo, da tistega, kar 
je iz nemščine, ne bomo smeli, pa se dajmo tega držati, da bodo vsi zadovoljni.« Lahko pa rečeš: »Zdaj sem pa kultivirani govorec in bom preganjal še vse druge stvari, s slehernim dnevom. «Zdi se mi, da ta tip zrelaksirane informacije o jeziku, pa tudi: ne se sekirati, ne podcenjevati otrok ... Zavedam se, da je moj otrok v drugem razredu pač otrok dveh jezikoslovcev, bog pomagaj. Ampak saj vidim tudi kakšnega sošolca, ki ni niti približno otrok jezikoslovcev (hvala bogu), pa jih sistem in vsi skupaj pretežno podcenjujejo. V tem, kaj opazujejo, pa kaj bi lahko opazili, pa česa ne razumejo. In prece- in podcenjujejo.

Polona Gantar: V bistvu ubiješ občutek, ki ga ...

Marko Stabej: Ja, voditi ta občutek in ne z nestrpnimi, izključujočimi izjavami - kot se to da. Zdi se mi, da je velik del tega še vedno tudi vprašanje zelo zgodnje pedagogike. Zadnjič na Obdobjih smo imeli priložnost slišati, da je bila kolegica, ki je pristojna za izobraževanje razrednih učiteljev, polna jeze na to, kaj učitelji počnejo v šolah. Izkazalo se je, da najbrž v glavnem pripisuje krivdo tistim, ki vzgajamo predmetne učitelje. To je po moje eden osrednjih problemov, kar sem že večkrat komentiral. V znanstveni skupnosti, kjer si to lahko privoščimo ... Je treba preskočiti $\mathrm{s}$ tem vprašanjem tudi $\mathrm{v}$ druge skupnosti. In najbrž ne brez bistveno ostrejših okroglih miz.

Špela Arhar Holdt: Še? Imamo čas za še eno vprašanje, ga bomo stisnili. Kar hitro, vem, da ste polni ...

Simon Krek: Lahko pa komentiram dalje? Po mojem je vseeno treba dodati eno stvar. Če se vprašamo, kakšna je slovenščina ali pa čigava je slovenščina v Janesu ... Kakšen je pa eden od namenov oz. zlobnih namenov Janesa? Da bi omogočil umetnointeligenčnim sistemom tudi razumevanje slovenščine - tudi razumevanje slovenščine, ki ni standardna. Slišali smo, da bo umetna inteligenca pač slej ali prej prevzela oblast in da ne more, če ne razume slovenščine. V tem smislu je to nov fenomen, to hočem reči. Nov fenomen, ki je res relativno mlad: da imamo dostop do vsega, kar je bilo prej privatno. Tu zadaj so sporočila, je neka vednost, ni samo standardna ali nestandardna slovenščina. 
Nekdo je hotel nekaj reči in potem merimo njegovo čustvenost, kaj je hotel povedati, ali mu je všeč audi ali mu je všeč fičko in tako naprej. $V$ končni fazi je eden od namenov Janesa: zato ker imamo nov fenomen, bomo to lahko počeli. In zdaj je treba te stvari, če dejansko hočemo to narediti, tudi uspešno narediti. Torej je treba razumeti vse. Vse, kar ta povprečni Janes misli, sporoča, pove.

Marko Stabej: Samo jaz se bojim, da bomo morali Janesa prej nadgraditi z Micko, kar se je v obliki GOS-a že začelo. Ker to je Janes na avtobusu, Janes v diskoklubu ... (smeh) Mislim, tu je tudi skušnjava (sicer dovolj reflektirana) pri marsikaterem prispevku: kaj je sedaj z govorjenim? V glavnem nimamo pojma, kaj je v bistvu govorjena slovenščina, še vedno ne. Čeprav vemo že marsikaj, česar nismo. To se mi zdi pohlep po ...

Simon Krek: Ja, ampak je tu še en dodatek. Kar mislimo, da je zdaj v privatni sferi govorjenega jezika, se bo v naslednjih letih drastično spremenilo. Ker se bomo non-stop snemali in bodo te stvari enostavno prešle $v$ isto, kar je zdaj Janes. In bo tudi govorjeni jezik tam.

Marko Stabej: Uh! (smeh) Potem bomo pa pazili, kako govorimo.

Špela Arhar Holdt: A se da to še kako ustaviti? (smeh) Ne, je še kakšno vprašanje?

Darja Fišer: Helena, mislim, da je hotela nekaj ...

Helena Dobrovoljc: Ne, ne.

Marko Robnik Šikonja: Mogoče bi jaz lahko še jaz nekaj? Glede norme, o kateri smo govorili. Mogoče bi bilo smiselno normo oblikovati tako, da bi umetna inteligenca dejansko lahko kaj razumela. To bi bilo treba upoštevati.

Špela Arhar Holdt: Bi se bilo treba prilagoditi ne samo uporabniku, ampak tudi umetni inteligenci? ... Ni kakšnega komentarja na to? Se strinjamo? Se strinjamo (smeh). Darja nam je dovolila, da - ker je debata zelo plodna in razburljiva - podaljšamo še za kakšnih deset minut. 
Marko Stabej: Ampak to jo bo zdaj ubilo.

Špela Arhar Holdt: Ja, da sem na glas povedala. Ko se nam je začelo muditi, je bilo bolj dinamično. Lahko še kakšno vprašanje iz publike? Prepričana sem, da imamo vsi mnenje ... Če ne, bom jaz še kaj vprašala ...

Helena Dobrovoljc: Lahko mogoče prej še nekaj na šolski sistem in na to, kaj pravzaprav z raziskovanjem nestandardne slovenščine pridobivamo? Zame je pomembno tudi, da je učitelj (če že govorimo tudi o predmetni stopnji, kjerkoli) - da je toliko seznanjen z jezikovnimi procesi in tudi spremembami, ki so žive, da otroku, ki napiše higijena namesto higiena, tega ne šteje v slabo. Ker se ta učitelj zaveda, da pred dvajsetimi leti v nobenem priročniku ni bilo napisano, da je prav amonijak, danes pa je. Da gre za nek jezikovni pojav, ki v jeziku ni zacementiran in se sčasoma prilagodi govorjenemu jeziku. To nam pravzaprav sporoča korpus nestandardne slovenščine Janes. In to je tisto: da take pojave $s$ pomočjo jezikovnotehnoloških analiz izluščimo. Da se pač zavedamo, na katerih področjih standarda govorimo o procesu, na katerih o dogovoru itd. Na to sem pomislila v Jezikovni svetovalnici, kamor je zadnjič prišlo vprašanje, da je v SSKJ in pravopisu9 zapisana le zveza biti občutljiv za (občutljiv za mraz, za svetlobo in tako naprej). Vse bolj pa uporabljamo tudi občutljiv na: na dotik in podobno. In občutljiv na se je preselil tudi na mraz, na svetlobo. Osebo je zanimalo, ali sme zapisati tudi zvezo občutljiv na. Dejansko se ljudje sprašujejo. V šolskem sistemu pa je pomembno, da so $\mathrm{S}$ stvarmi glede nestandarda v taki meri seznanjeni, da znajo ne zatolči otrok, ki so mogoče že korak pred nami. To je to.

Špela Arhar Holdt: Tako, spet se obračam na publiko, če se bo še kdo opogumil ... Mogoče za zaključek, preden povzamemo debato, zoom out, razširitev na širše jezikovnopolitično področje. Če se moramo odzvati in nam korpus Janes ponuja možnost, da se opredelimo do nečesa, do česar se nam prej

\footnotetext{
9 Slovar slovenskega knjižnega jezika in Slovenski pravopis 2001 sta dostopna na portalu Fran: www.fran.si.
} 
še ni bilo potrebno opredeliti, bi vprašala tole: želimo si, da bi od zdaj naprej šla standardizacija v smer urejanja tistih delov jezika, ki povzročajo težave - najbrž v smer zmanjševanja teh težav. Torej bi lahko standardni jezik videli kot tisti del jezika, kjer je jezikoslovna intervencija dejansko pomoč. Lahko bi se omejili na ta del in s tem najbrž razočarali del javnosti, ki pričakuje od nas, da bomo non-stop intervenirali, vrednotili in se opredeljevali tudi do tistega dela jezika, ki ga naj ne bi poskušali standardizirati. Kakšna misel? To je bilo vprašanje, v bistvu teza, ne vem.

Polona Gantar: Ko si včeraj dala navodila, da moramo na koncu poslati oz. povedati sporočilo za domov, sem si zapisala, da je »korpus Janes kot korpus nestandardne slovenščine dober vir za oblikovanje novega standarda «. Mislim, da je Janes v tem trenutku eden najbolj raziskanih, z metapodatki najbolje opremljenih korpusov. In pokazalo se je točno to: tukaj se nekaj dogaja situacije, s katerimi se kot jezikoslovci še nismo srečali, sedaj pa se z njimi ukvarjamo. Pomembno se mi zdi tole: imamo nestandardni korpus in ga bomo uporabili za to, da bomo določali standard. To se mi zdi fajn, provokativna misel. Hkrati pa za jezikoslovce pomeni hudo nalogo, ker bo treba ločiti, kaj je namerni odstop (da ga ne bomo sedaj standardizirali) in kaj je tisto, kar se mogoče dogaja globlje - ustaljeno, normalno obnašanje $\mathrm{v}$ jeziku, kot recimo primer levega prilastka, pa vejice in tako naprej. Slednje se mi pa zdi smiselno pri novem standardu upoštevati.

Damjan Popič: Povedal bi samo, da se mi zdi odlično, da so raziskovalci pri Janesu uspeli vzpostaviti paralelno strukturo oz. večtirni sistem: da na eni strani (kjer je to mogoče, recimo pri tvitih) vemo, kateri uporabniki so korporativni in kateri so zasebni. Na tak način spremljamo jezikovno dinamiko, vidimo morebitne relevantne spremembe. Po drugi strani pa so uspeli določiti standardnost posameznih tvitov. Tu so zagotovo morali sprejemati težke odločitve, ampak so jih na koncu sprejeli in imajo razvidne kriterije za to. To je nekako to, kar v resnici počnemo: določamo, kaj je manj standardno, bolj standardno in tako naprej. 
Simon Krek: Moja zaključna misel? Tako bom rekel: res je ključno, da ne gasimo, kjer ne gori. V smislu, da rečemo, ne vem: »Burke so prepovedane.« »Hu, a veš, da je burka prepovedana, od včeraj. « Nikjer daleč naokrog pa nihče ne nosi burk. To velja tudi za jezikovne fenomene, sami si lahko zagrenimo jezik z umetnimi problemi. Drugo pa je tisto, kar je zapisano v tej knjigi čisto na koncu članka, ki ga imamo z Damjanom in Vojkom: ${ }^{10}$ da bi si res morali prizadevati, da lahko vsak govorec slovenščine vsak trenutek sam interpretira vse okoliščine rabe kateregakoli izraza. Vse te korpuse rabimo, da lahko omogočimo ljudem, da sami obvladujejo svoj jezik. Da ne rabijo ves čas pomočnika, ki ga sprašujejo: »A je burka sedaj dovoljena ali prepovedana, aha, včeraj je bila še, zdaj pa ni več.«

Helena Dobrovoljc: Kot sem že prej nakazala: za nas je raziskava nestandardnega jezika pomembna v smislu raziskave centrifugalnih sil. Da se tudi ob tem odločamo za standardizacijski postopek, ki bi bil čimbolj univerzalističen. To bi bilo moje stališče. S tem, da se ne sprejema v standard zgolj prestižnih prvin, ampak tudi tiste, ki jih zaznavamo kot na nek način nove in sistemsko drugačne. Da prepoznamo, kot je omenila Polona, sporadične, posamezne primere in pa sistemske, kategorialne spremembe.

Marko Stabej: Poljubna slovenščina ni kr ena slovenščina, ampak pomeni poljub z jezikom. (smeh)

\section{Darja Fišer: Francoski! (smeh)}

Špela Arhar Holdt: Francoski, ja, nestandardni! Res super, najlepša hvala vsem panelistom, mislim, da smo res dobro opravili nalogo, najlepša hvala publiki. Mislim, da smo danes odprli veliko vprašanj - nismo čisto vsega še zaprli, ampak nekaj dela pa le moramo pustiti še za ostale. Najlepša hvala.

${ }^{10}$ Gre za prispevek z naslovom Med ideologijo knjižnega in standardnega jezika (Gorjanc in dr. 2015). 


\section{LITERATURA}

Arhar Holdt, Š. in Dobrovoljc, K. (2015): Zveze samostalnika z nesklonljivim levim prilastkom v korpusih Janes in Kres. V D. Fišer (ur.): Zbornik konference Slovenščina na spletu in $v$ novih medijih: 4-9. Ljubljana: Znanstvena založba Filozofske fakultete.

Aritmični concert Hamo \& Tribute to Love. Dostopno v arhivu RTV Slovenija:

http://ava.rtvslo.si/predvajaj/aritmicni-koncert-hamo-tribute-2-love/ava2.174373497/ (11. marec 2016).

Bakhtin, M. M. (1981): The Dialogic Imagination: Four Essays. Austin: University of Texas Press.

Bitenc, M. (2013): Z Idrijskega v Ljubljano: sociolingvistični pogled. V A. Naterer (ur.): Socializacija in socialne formacije, Subkulture, Tematska izdaja, št. 12-13: 106-125. Maribor: Subkulturni azil, zavod za umetniško produkcijo in založništvo.

Center za slovenščino kot drugi ali tuji jezik. Dostopno prek: http://www.centerslo.net/ (11. marec 2016).

Erjavec, T., Fišer, D. in Ljubešić, N. (2015): Razvoj korpusa slovenskih spletnih uporabniških vsebin Janes. V D. Fišer (ur.): Zbornik konference Slovenščina na spletu in $v$ novih medijih: 2026. Ljubljana: Znanstvena založba Filozofske fakultete.

Fran, slovarji Inštituta za slovenski jezik Frana Ramovša ZRC SAZU, različica 3.o. Dostopno prek: www.fran.si (11. marec 2016).

Gigafida. Dostopno prek: http://www.gigafida.net (11. marec 2016).

Gorjanc, V., Gantar, P., Kosem, I. in Krek, S. (ur.) (2015): Slovar sodobne slovenščine: problemi in rešitve. Ljubljana: Znanstvena založba Filozofske fakultete.

Gorjanc, V., Krek, S. in Popič, D. (2015). Med ideologijo knjižnega in standardnega jezika. V V. Gorjanc in dr. (ur.): Slovar sodobne slovenščine: problemi in rešitve: 32-48. Ljubljana: Znanstvena založba Filozofske fakultete. 
Gos. Dostopno prek: www.korpus-gos.net (11. marec 2016).

Jezikovna svetovalnica Inštituta za slovenski jezik Frana Ramovša ZRC $S A Z U$. Dostopno prek: http://isjfr.zrc-sazu.si/svetovalnica (11. marec 2016).

Krek, S. (2015): Grafika Standardni in knjižni jezik. Dostopno prek: http://nl.ijs.si/janes/dogodki/konferenca-2015/\#Okrogla_miza (11. marec 2016).

Krek, S. (2015): Slovenska slovnica in računalniško procesiranje besedil v slovenščini. Predavanje na portalu Videolectures: http://videolectures.net/solomon_krek_slovenska_slovnica/ (11. marec 2016).

Krek, S. (2015): Standardni in knjižni jezik - drugi poskus. V: M. Smolej (ur.): Slovnica in slovar - aktualni jezikovni opis: 401-407. Ljubljana: Znanstvena založba Filozofske fakultete.

Kres. Dostopno prek: www.korpus-kres.net (11. marec 2016).

Logar, N., Grčar, M., Brakus, M., Erjavec, T., Arhar Holdt, Š. in Krek, S. (2012): Korpusi slovenskega jezika Gigafida, KRES, ccGigafida in ccKRES: gradnja, vsebina, uporaba. Ljubljana: Trojina, zavod za uporabno slovenistiko; Fakulteta za družbene vede.

Miličević, M. (2015): Beyond example extraction: Quantitative analysis of the JANES corpus. Gradiva delavnice dostopna prek: http://nl.ijs.si/janes/dogodki/konferenca-2015/\#Predkonferencni_tutorial (11. marec 2016).

Obdobja 34: Slovnica in slovar - aktualni jezikovni opis. Dostopno prek: http://centerslo.si/simpozij-obdobja/arhiv-simpozijev-obdobja/2015-2/ (11. marec 2016).

Projekt Janes, jezikoslovna analiza nestandardne slovenščine. Dostopno prek: http://nl.ijs.si/janes/ (11. marec 2016).

Skubic, A. E. (2005): Obrazi jezika (Knjižna zbirka Posebne izdaje). Ljubljana: Študentska založba.

Tomažič, A. (2015): Internet, roboti in nov družbeni red. Pogledi, let. 6, št. 11, 10. junij 2015. Dostopno prek: http://www.pogledi.si/druzba/internet-robotinov-druzbeni-red (11. marec 2016). 
Slovenščina 2.o, 2 (2016)

Verdonik, D. in Zwitter Vitez, A. (2011): Slovenski govorni korpus Gos. Ljubljana: Trojina, zavod za uporabno slovenistiko. 


\section{THE JANES SLOVENE: INFORMAL, NON- STANDARD, ONLINE OR, MERELY, SLOVENE}

To delo je ponujeno pod licenco Creative Commons: Priznanje avtorstvaDeljenje pod enakimi pogoji 4.o Slovenija.

This work is licensed under the Creative Commons Attribution ShareAlike 4.0 License Slovenia.

http://creativecommons.org/licenses/by/4.0/

(c) (i) (2) 